\title{
Tinjauan Relevansi Tret Personaliti Kaunselor Muslim di Institusi Pendidikan Tinggi Melalui Profil Personaliti TAJMA
}

\author{
Hasbullah Hj Abu Kassimª, Ahmad Syukran Baharuddin ${ }^{\mathrm{b}}$, Mohd Tajudin Ninggala \\ ${ }^{a}$ Fakulti Pendidikan, Universiti Teknologi Malaysia, 81310 UTM Johor Bahru, Johor, Malaysia \\ ${ }^{\mathrm{b}}$ Fakulti Tamadun Islam, Universiti Teknologi Malaysia, 81310 UTM Johor Bahru, Johor, Malaysia
}

*Corresponding author: hasbullah25@live.utm.my

\begin{abstract}
The psychometric knowledge base created by the West to dominate the psychological counseling in the national higher education sector. Towards Independence Day celebration of the country to 59 years, it was time for psychological counseling knowledge groove countries on the psychometric creation by local Muslims scholar's. This paper discusses the relevance of two (2) trait of 12 personality traits through Islam by psychometric perspective TAJMA Personality Profile. This finding would indicate empirical personality traits necessary to be a Muslim counselor in the improvement of guidance and counseling services organization. Data from 27 Muslim counselors in higher education institutions Malaysia were analyzed and as a conclusion, personality trait of Assertive and Caring among muslim counsellors are salient for improving their competence and knowledge.
\end{abstract}

Keywords: Relevancy; muslim counsellor personality; psychometric; TAJMA personality profile

Abstrak

Psikometrik ciptaan Barat mendominasi asas pengetahuan psikologi kaunseling di sektor pendidikan tinggi negara. Menjelang sambutan kemerdekaan negara yang ke 59 tahun, sudah sampai masanya alur pengetahuan psikologi kaunseling negara berlandaskan kepada psikometrik ciptaan muslim tempatan. Kertas ini membincangkan relevansi dua (2) tret dari 12 tret personaliti melalui perspektif Islam mengikut psikometrik Profil Personaliti TAJMA. Dapatan ini akan menunjukkan secara emperikal tret personaliti yang sewajarnya perlu pada seorang kaunselor muslim dalam peningkatan perkhidmatan bimbingan dan kaunseling organisasi. Data dari 27 orang kaunselor muslim institusi pendidikan tinggi awam Malaysia telah dianalisis dan rumusannya tret personaliti Asertif dan Prihatin penting pada kaunselor muslim untuk kompetensi diri dan pengetahuan profesionnya.

Kata Kunci: Relevansi; personaliti kaunselor muslim; psikometrik; profil personaliti TAJMA

(C) 2016 Penerbit UTM Press. All rights reserved

\subsection{PENGENALAN}

Malaysia memperuntukan pelaburan yang tinggi dalam dalam pendidikan sejak negara mencapai kemerdekaan lebih 58 tahun yang lalu. Jumlah peruntukan yang besar sentiasa diutamakan kepada sektor pendidikan malahan pada tahun 2012, Kementerian Pendidikan Malaysia menerima RM36 bilion atau 16\% daripada jumlah bajet negara dan membuktikan bahawa pendidikan adalah antara keutamaan negara. Falsafah Pendidikan Kebangsaan menyatakan untuk melahirkan rakyat Malaysia pendidikan di Malaysia adalah suatu usaha berterusan ke arah memperkembangkan lagi potensi individu secara menyeluruh dan bersepadu untuk mewujudkan insan yang seimbang dan harmonis dari segi intelek, rohani, emosi dan jasmani berdasarkan kepercayaan dan kepatuhan kepada Tuhan. Usaha ini adalah bagi melahirkan rakyat Malaysia yang berilmu pengetahuan, berketerampilan, berakhlak mulia, bertanggungjawab, dan ber-keupayaan mencapai kesejahteraan diri serta memberi sumbangan terhadap keharmonian dan kemakmuran keluarga, masyarakat dan negara. Perkhidmatan bimbingan dan kaunseling di sektor pendidikan di Malaysia sudah mencecah usia 53 tahun (sejarah bimbingan dan kaunseling di Malaysia bermula sejak tahun 1963 (Mizan Adiliah Ahmad Ibrahim, 2001; Muhd Mansur Abdullah, 1993). Justeru itu, sudah sampai masanya struktur kompetensi profesi kaunselor seiring dengan arus masa kini. Ini bermakna, kaunselor perlu ada perubahan diri seperti pengetahuan dan kemahiran. Dalam kajian lain menyatakan bahawa perlunya seorang kaunselor mengikuti pendidikan lanjutan seandainya mahu kepada mutu perkhidmatan lebih efisien (Ab Rahim Bakar, Noor Syamilah Zakaria, \& Shamsiah Mohamed, 2011).

\subsection{ASAS KAJIAN}

Jumlah kaunselor berdaftar di Lembaga Kaunselor Malaysia (LKM) sudah mencapai 6000 orang (Urusetia Lembaga Kaunselor Kementerian Pembangunan Wanita Keluarga dan Masyarakat, 2015). Dari sejumlah itu, didapati hampir 75\% adalah terdiri dari kaunselor muslim, lelaki dan wanita. Oleh yang demikian, bagaimanakah trait personaliti kaunselor muslim Malaysia yang perlu dan apakah ada alat 
ukur personaliti ciptaan kaunselor muslim Malaysia masa kini? Kajian ini akan mengupas tret-tret personaliti yang perlu pada personaliti kaunselor muslim di Malaysia mengikut Profil Personaliti TAJMA Edisi 2 (PPT2).

\section{Kaunselor Muslim Dan Perkhidmatan Kaunseling Di Malaysia}

Tuntutan kerja buat berkualiti dari kaunselor sangat dituntut oleh majikan di sesebuah organisasi. Di sekolah, perkhidmatan kaunselor diperlukan untuk memastikan setiap murid mampu menyumbang dalam kecemerlangan akademik ataupun sahsiah. Manakala di peringkat Kementerian Pendidikan, penubuhan Bahagian Psikologi dan Kaunseling pada tahun 2008 adalah tepat dalam memastikan warga guru dan warga bukan guru berupaya menjadi modal insan berkualiti (Kementerian Pendidikan Malaysia, 2015).

Laporan Kementerian Pendidikan Malaysia 2011 ada menyatakan walaupun terdapat guru cemerlang di dalam sistem pendidikan namun hanya 50\% sahaja pengajaran dan pembelajaran berjaya disampaikan dengan berkesan (Kementerian Pendidikan Malaysia, 2012). Zaman kepesatan teknologi dan pembangunan negara kini memberikan tekanan dan impak terhadap pengajaran dan pembelajaran. Justeru itu, tuntutan kemahiran psikologi diri dalam pengajaran dan pembelajaran akan membantu keberkesanan pemahaman murid (Dinkelman, 2011; Harris, Ingle, \& Rutledge, 2014; Openshaw, Linden, \& Linden, 1969).

Seorang kaunselor merupakan individu yang mengadakan dan memberikan khidmat kaunseling bagi suatu fee yang ditetapkan dan seorang kaunselor berdaftar di Malaysia adalah seseorang yang didaftarkan di bawah Seksyen 26 dan 27 di dalam Akta kaunselor 1998 (UndangUndang Malaysia, 1998). Berdasarkan Akta kaunselor 1998 itu, khidmat kaunseling adalah suatu proses sistematik untuk membantu perhubungan berdasarkan prinsip-prinsip psikologi yang dilaksanakan oleh kaunselor berdaftar mengikut kod etika kaunseling untuk mencapai suatu perubahan, kemajuan dan penyesuaian yang holistik, baik pada sukarela pada diri klien supaya perubahan, kemajuan dan penyesuaian itu akan berterusan sepanjang hayat klien.

Pernyataan itu memberikan sejumlah persepsi bahawa unsur personaliti tidak mempunyai kaitan dengan perkhidmatan itu melainkan dalam Peraturan-Peraturan kaunselor (Kelakuan Dan Tatatertib) Peraturan-Peraturan kaunselor (Pendaftaran dan Perakuan Amalan 1999), Bahagian II No.3 (3) yang menjelaskan bahawa seorang kaunselor perlu menyatakan kepakaran dan tahap kecekapannya kepada pihak majikan dan organisasi. Justeru, dengan frasa tersebut menunjukkan seorang kaunselor muslim wajar mengambil inisiatif kendiri dalam menjaga identiti Islam yang disandangnya melalui personaliti. Persoalan yang wujud adalah apakah bentuk personaliti yang perlu bagi seorang kaunselor muslim itu? Kajian ini akan berusaha memperjelaskan persoalan tersebut.

\section{Personaliti dan Akhlak Islam}

Tiada yang dapat memberikan secara tepat berkenaan definisi personaliti kerana penjelasannya adalah berbeza mengikut situasi, tingkah laku dan alat ukurnya (Gregory J.Boyle, 2008; Habibah Elias dan Noran Fauziah Yaakub, 2002). Personaliti adalah manusia sebagai diri sendiri (Dewan Bahasa Pustaka, 1991). Personaliti berasal dari kata bahasa Latin bermaksud persona atau topeng. Topeng itu adalah bersifat luaran. Terdapat dua sisi penting personaliti iaitu individu secara keseluruhan dan perbezaan individu. Neufeldt (1994) menyatakan personaliti bergantung kepada fizikal mahupun mental individu yang menentukan corak tingkah laku. Pernyataan itu ada kebenarannya, kerana tingkah laku menentukan personaliti kerana sifatnya yang dinamis dan unik (Sidek Mohd Noah, 2006).

Personaliti tiada dinyatakan di dalam Al-Quran melainkan perkataan akhlak.yang paling hampir menggambarkan personaliti. Terdapat sembilan bahagian dalam kitab terjemahan Al-Quran berkaitan akhlak (Rasm Uthmani, 2014). Disebabkan manusia mempunya dua (2) jenis jiwa iaitu rendah yang ingin kelazatan, kesedapan dan menderhaka. Manakala jenis jiwa yang kedua kedua jiwa tinggi iaitu suka kepada pengorbanan, mematuhi akal dan meninggikan akhlak (Hasan Langgulung, 1997; Rusleda Awang, Wan Kamal Mujani, 2012). Personaliti mempengaruhi manusia di sekelilingnya termasuk sikap dan tingkah laku. Berdasarkan firman Allah:

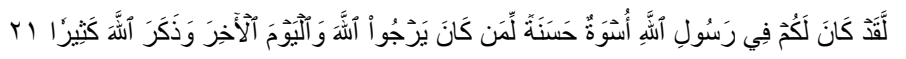

Maksudnya:

"Sesungguhnya adalah bagimu pada diri Rasulullah SAW itu contoh ikutan yang baik buat orang-orang yang mengharapkan Berjumpa dengan Allah dan hari akhirat dan selalu ingat terhadap Allah".

Al Ahzab, ayat 21.

Ikutan yang dimaksudkan adalah akhlak atau personaliti Muhammad SAW (Abdul Mun'im Al Hasyimi, 2012; Pahrol Mohamad Juoi, 2010). Akhlak Nabi Muhammad SAW adalah contoh sepanjang zaman untuk kehidupan manusia dan adalah sistem paling akurat dalam mencapai kesempurnaan akhlak dan moral (Sayyid Mujtaba Musavi Lari, 1995). Justeru, Mohd Puzhi Usop (2013), menyatakan manusia perlu sentiasa diperingatkan agar akhlak dan matlamat diri kembali kepada matlamat asal. Berdasarkan firman Allah

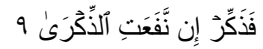

Maksudnya:

"Berilah peringatan kerana peringatan itu bermanfaat"

Surah Al A`la, ayat 9

Ayat tersebut bertepatan dengan tugas seorang kaunselor yang memberikan ingatan, nasihat atau puji-pujian agar pelajar mempunyai akhlak mulia, berilmu dan berdaya saing dalam kehidupan semasa. Al-Ghazali memberikan tiga (3) pendekatan yang disebut al-Quran dalam menyampaikan mesej ilmu iaitu pendekatan al-Mawizah (memberi nasihat untuk orang awam); pendekatan al-Hikmah untuk golongan cendekiawan; dan pendekatan al-Mujadalah untuk golongan yang membantah. Bersesuaian dengan firman Allah,

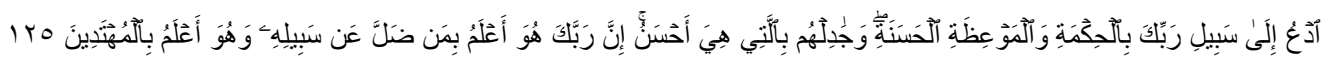


Maksudnya:

Surah al-Nahl, ayat 125

"Serulah ke jalan Tuhanmu (wahai Muhammad) dengan hikmat kebijaksanaan dan nasihat pengajaran yang baik, dan berbahaslah dengan mereka (yang engkau serukan itu) dengan cara yang lebih baik; sesungguhnya Tuhanmu Dia lah jua yang lebih mengetahui akan orang yang sesat dari jalanNya, dan Dia lah jua yang lebih mengetahui akan orang-orang yang mendapat hidayah petunjuk"

Surah al-Nahl, ayat 125

Dengan hikmah kebijaksanaan dan nasihat pengajaran yang baik dan berbahaslah dengan yang lebih baik (Mohd Fauzi Hamat, 2005). Tujuan pendidikan dalam Islam adalah bersumberkan kepada Quran dan Hadis (Rusleda Awang, Wan Kamal Mujani, 2012). Pelbagai kajian berkonsepkan Islam menunjukkan bahawa personaliti merupakan salah satu elemen terpenting dalam pengajaran dan pembelajaran (Ismail \& Yusuf, 2012; Suhid, 2012) dan malah akidah sebagai manhaj utama pembentukan akhlak yang berpandukan kepada al-Quran dan al-Sunnah serta hubungkait antara iman dan akhlak ke arah pembentukan peribadi unggul pelajar muslim (Hishamuddin Abdul Hamid, Mohd Isa Hamzah, Rohizan Ya, Suriani Abd Rahim, \& Khairul Najah Abdul Rahim, 2012). Personaliti Muslim itu adalah mempunyai pegangan agama yang kuat. Terdapat beberapa maksud berkaitan dengan kenyataan 'pegangan agama yang kuat' antaranya tawaduk, sabar, berkata baik, ceria, jujur, murah hati, lemah lembut, dipercayai, pemaaf, kasih sayang, menepati janji dan menjaga persaudaraan sesama Muslim (Abdul Hafiz Mat Tuah, Zakaria Stapa, \& Ahmad Munawar Ismail, 2012; Buerah Tunggak, 2011; Zakaria Stapa, Noranizah Yusuf, 2012). Anjuran menghiasi diri dengan berakhlak mulia adalah nasihat paling diutamakan oleh Nabi Muhammad SAW. Baginda bukan hanya menganjurkan malahan mempraktik amalan itu. Kedapatan orang-orang bukan Islam di zaman baginda memeluk Islam hanya kerana akhlak mulia yang ditunjukkan oleh Nabi Muhammad SAW. Akhlak mulia baginda Muhammad SAW tidaklah terhitung banyaknya namun terdapat 41 akhlak Muhammad SAW yang telah tercatat untuk dijadikan pedoman atau contoh masa kini (Muhadir Hj Joll, 2014). Pembangunan akhlak adalah dasar utama dalam semua kebaikan di kehidupan dunia ini.

Firman Allah,

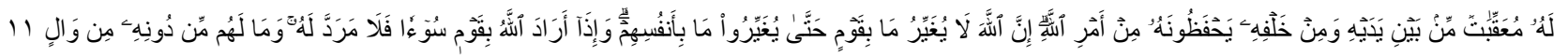

Maksudnya:

"Sesungguhnya Allah SWT tidak mengubah apa yang ada pada sesuatu kaum sehingga mereka mengubah apa yang ada pada diri mereka sendiri. Dan apabila Allah SWT menghendaki untuk menimpakan kepada sesuatu kaum bala bencana (disebabkan kesalahan mereka sendiri), maka tiada sesiapapun yang dapat menolak atau menahan apa yang ditetapkanNya itu, dan tidak ada sesiapapun yang dapat menolong dan melindungi mereka selain daripadaNya'.

Surah Ar-Rad:11

Kesimpulannya, seorang guru yang meneladani Al Quran dan Sunnah Muhammad SAW pada personalitinya, akan sentiasa memelihara perilaku mahupun tutur kata agar pengajaran dan pembelajaran dapat memberikan impak dan kefahaman yang tersentuh di hati dan pemikiran (Muhammad Al-Ghazali, 2002). Pendidikan seperti ini bukan sahaja mampu meliputi urusan dunia malahan ke akhirat. Guru yang mahir dalam psikologi dan tekniknya adalah suatu kelebihan dalam meningkatkan pengajaran dan pembelajaran (Martyn Long, 2000; Millon, 2003). Sejumlah perilaku manusia di dalam pendidikan boleh diketahui melalui psikologi (Bembenutty, 2010; Chickering, 2010) Pelbagai kajian menyokong peranan personaliti dalam pengajaran dan pembelajaran serta berpengaruh kepada pencapaian akademik (Geramian, Mashayekhi, \& Mohd Tajudin Ninggal, 2012; Komarraju, Karau, Schmeck, \& Avdic, 2011).

\section{Psikometrik Profil Personaliti TAJMA Edisi 2 (PPT2)}

Penggunaan psikometrik Barat sudah lama digunakan di Malaysia namun tidak terdapat banyak ujian yang direka bentuk mengikut budaya dan psikologi masyarakat Malaysia khususnya dalam mendapatkan profil individu (Mohd Tajudin Ninggal, 2012). PPT2 dicipta oleh Mohd Tajudin Ninggal (Profesor Psikologi Kaunseling), Universiti Teknologi Malaysia dan menerima hakcipta pada tahun 2003. PPT2 sebagai instrumen kajian ini mempunyai nilai-nilai dan norma masyarakat Malaysia (Malaysian Psychology). Kebolehpercayaan PPT2 pada nilai $\alpha 0.90$ melalui Teori Ujian Klasikal dan nilai $\alpha 0.99$ melalui Teori Respon Item adalah menepati ciri kredibiliti psikometrik (Akbariah Mohd Mahdzir, 2015; Chua Yan Piaw, 2012; Haslina Hanapi, 2012; Mohd Tajudin Ninggal, 2014). PPT2 ini mengandungi 90 item yang mengukur 12 tret personaliti diri iaitu Asertif, Analitikal, Keterbukaan, Keyakinan Diri, Kepimpinan, Jati Diri, Prihatin, Silang Budaya, Pencapaian, Integriti, Patriotisme dan Ketidakselarasan. PPT2 mempunyai tiga tahap intepretasi iaitu tahap tinggi, sederhana dan rendah.

\section{Trait Personaliti Asertif (AS) dan Tret Personaliti Prihatin (PT) Melalui Perspektif Islam}

Kajian ini berfokus kepada dua (2) tret personaliti mengikut psikometrik PPT2. Tret personaliti AS PPT2 dideskripsikan kecenderungan manusia untuk mempamerkan tahap ketegasan diri atau takut dan mudah dimanipulasikan oleh orang lain khususnya dalam kehidupan seharian.

Firman Allah

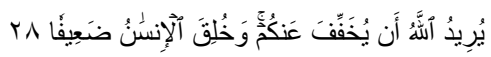

Surah An-Nisa, ayat 28

Maksudnya:“Allah (sentiasa) hendak meringankan (beban hukumnya) daripada kamu, kerana manusia itu dijadikan berkeadaan lemah. Pernyataan ini memberikan gambaran bahawa kehidupan manusia sentiasa berubah dan adalah ujian dari Allah SWT (Yatimah Sarmani dan Mohd Tajudin Ninggal, 2008). 
Firman Allah,

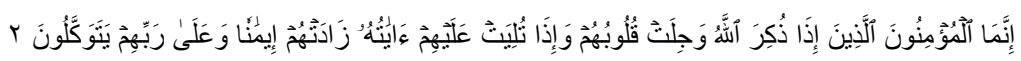

Surah Al-Anfal ayat 2

bermaksud "sesungguhnya orang yang beriman adalah mereka yang apabila disebut nama Allah SWT, maka bergeraklah hati mereka. Dan apabila dibacakan kepada mereka ayat-ayat-Nya, bertambahah iman mereka kerananya. Dan kepada Allah SWT mereka bertawakal".

Tret AS ini memberikan makna ketegasan dan takut atau mudah dimanipulasikan orang lain itu adalah milik Allah SWT. Walau bagaimanapun, kecenderungan yang terlalu takut bakal menimbulkan kemudaratan kepada manusia serta memberikan imej Muslim yang tidak baik kepada bukan Muslim. Sehinggakan tret AS ini berupaya menjelaskan mudahnya manusia mengikut apajua kehendak orang lain kerana takut dirinya diapa-apakan baik secara fizikal ataupun peluang kenaikan pangkat dibekukan. Justeru, ketakutan yang benar adalah tidak mahu ikut sama melakukan dosa seperti pecah amanah ataupun bersubahat dalam penipuan (Muhammad Uthman Najati, 2012).

Tret personaliti AS turut menunjukkan kecenderungan manusia untuk bersikap agresif seandainya melibatkan hak-haknya dicerobohi malahan kecenderungan individu untuk beremosi marah adalah turut dijangkakan melalui tret personaliti AS. Marah antara emosi yang manusia yang Allah SWT rakamkan,

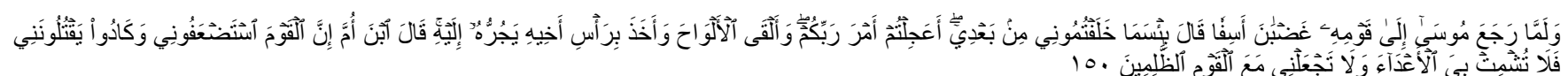

Surah A'Raf ayat 150

bermaksud "Dan tatkala Musa telah kembali kepada kaumnya dengan marah dan sedih hati berkatalah dia: Alangkah buruknya perbuatan yang kamu kerjakan sesudah kepergianku! Apakah kamu hendak mendahului janji Tuhanmu?" Dan Musa pun melemparkan luh-luh (Taurat) itu dan memegang (rambut) kepala saudaranya (Harun) sambil menariknya ke arahnya. Harun berkata: Hai anak ibuku, sesungguhnya kaum ini telah menganggapku lemah dan hampir-hampir mereka membunuhku, sebab itu janganlah kamu menjadikan musuh-musuh gembira melihatku, dan janganlah kamu masukkan aku ke dalam golongan orang-orang yang lalai"

Telah dinyatakan oleh Mohamed Hatta Shahrom (2008) bahawa salah satu asas akhlak mengikut Imam Al-Ghazali iaitu AlSyajaah iaitu keupayaan mengawal kemahuan emosi dan berfikir rasional. Dengan terabainya asas akhlak ini, ketidakseimbangan emosi, kesombongan dan rasa rendah diri akan menguasai manusia itu.

Tret personaliti kedua adalah prihatin (PT) yang PPT2 menjelaskan kecenderungan manusia mempamerkan sifat empati dalam memahami perasaan dan membantu orang lain. Tret ini amat relevan dengan sepertimana yang di dalam Firman Allah,

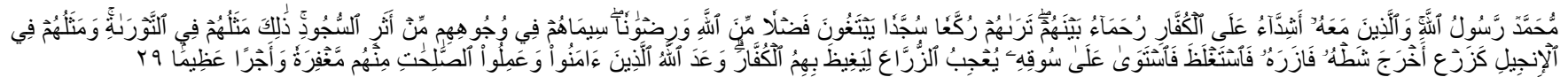

Surah al-Fath ayat 29

bermaksud "Nabi Muhammad (s.a.w) ialah Rasul Allah; dan orang-orang yang bersama dengannya bersikap keras dan tegas terhadap orang-orang kafir yang (memusuhi Islam), dan sebaiknya bersikap kasih sayang serta belas kasihan kasihan sesama sendiri (umat Islam). Engkau melihat mereka tetap beribadat rukuk dan sujud, dengan mengharapkan limpah kurnia (pahala) dari Tuhan mereka serta mengharapkan keredaanNya. Tanda yang menunjukkan mereka (sebagai orang-orang yang soleh) terdapat muka mereka - dari kesan sujud (dan ibadat mereka yang ikhlas). Demikianlah sifat mereka yang tersebut di dalam Kitab Taurat; dan sifat mereka di dalam Kitab Injil pula ialah: (bahawa mereka diibaratkan) sebagai pokok tanaman yang mengeluarkan anak dan tunasnya, lalu anak dan tunasnya itu menyuburkannya, sehingga ia menjadi kuat, lalu ia tegap berdiri di atas (pangkal) batangnya dengan keadaan yang mengkagumkan orang-orang yang menanamnya. (Allah menjadikan sahabat-sahabat Nabi Muhammad, s.a.w dan pengikut-pengikutnya kembang biak serta kuat gagah sedemikian itu) kerana Ia hendak menjadikan orang-orang kafir merana dengan perasaan marah dan hasad dengki - dengan kembang biaknya umat Islam itu. (Dan selain itu) Allah telah menjanjikan orang-orang yang beriman dan beramal soleh dari mereka, keampunan dan pahala yang besar".

Ayat ini menjelaskan hubungan tret personaliti AS dan PT berhubungkait antara satu sama lain. Kedua-dua tret ini tidak lain yang akhirnya akan menuju kepada pengabdian langsung kepada Allah SWT seperti,

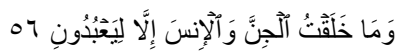

Bermaksud: "Dan Aku tidak menciptakan jin dan manusia melainkan untuk mereka menyembahKu".

Surah al-Zariyat: ayat 56

Pemupukan kasih sayang antara manusia adalah penting dalam tujuan memakmurkan dunia (Ratna Roshida Abd. Razak \& Nik Haslinda Nik Hussain, 2007). Tret personaliti PT yang rendah menjelaskan ketidakpekaan manusia kepada keadaan persekitarannya seperti kurangnya berbuat amal seperti menziarahi orang sakit, kurang terlibatan dalam aktiviti berpersatuan, kurang penampilan diri dan adab komunikasi serta pergaulan yang lemah khususnya dengan pelbagai bangsa atau kaum. Melalui gambaran tret personaliti AS dan PT secara langsung akan memberikan impak kepada mutu perkhidmatan bimbingan dan kaunseling oleh kaunselor muslim. 


\subsection{OBJEKTIF KAJIAN}

Kajian ini akan meninjau corak dua (2) tret profil personaliti PPT2 iaitu Asertif (AS) dan Prihatin (PT) pada kaunselor yang sedang berkhidmat Institusi Pendidikan Tinggi Awam (IPT) sebagai data sokongan. Kajian ini akan melihat tret Asertif (AS) dan tret Prihatin (PT). Kedua tret ini merupakan relevan dengan isu-isu dunia kaunseling kini (ACA Governing Council, 2014; Gladding, 2004; McLeod, 2007; Wheeler \& Hewitt, 2004).

\subsection{METODOLOGI KAJIAN}

Kaedah persampelan bertujuan digunakan kepada 27 orang responden manakala penggunaan psikometrik PPT2 secara dalam talian sebagai alat pengumpulan data. Kesemua responden itu merupakan peserta bengkel pertauliahan praktis PPT2 yang dikendalikan oleh pengasas PPT2. Data yang diperolehi dalam talian secara langsung memanimalkan kesilapan analisis dan menjimatkan masa pentadbiran (Mohd Tajudin Ninggal, 2014a, 2014c). Kajian tinjauan ini berupaya membantu dalam mengetahui keberkesanan sesuatu praktis serta menjawab beberapa persoalan dari pelbagai perspektif khususnya dalam menjelaskan perihal sikap, pandangan, kepercayaan, perasaan, dan perilaku (Chua Yan Piaw, 2012). Kaedah tinjauan dengan reka bentuk rentas berupaya mengukur sesuatu praktis dan perilaku masakini, (Creswell, 2012; Othman Talib, 2013). Atas pertimbangan etika profesion, nama responden dan nama IPT berkaitan tidak dinyatakan.

\subsection{DAPATAN KAJIAN}

Jadual 1 menunjukkan lebih $70 \%$ responden terdiri daripada golongan responden wanita dan 20\% daripada responden golongan lelaki. Situasi ini memberikan suatu isyarat bahawa perkhidmatan bantuan profesional menjadi pilihan wanita sebagai kerjaya di IPT. Situasi yang sama berlaku di profesion perguruan (Ab. Halim Tamuri, Muhamad Faiz Ismail, 2012).

Jadual 1 Taburan peratusan jantina responden

\begin{tabular}{ccc}
\hline Jantina & Jumlah & Peratus (\%) \\
\hline Lelaki & 6 orang & 22.2 \\
Perempuan & 21 orang & 77.8 \\
Jumlah & 27 orang & 100 \\
\hline
\end{tabular}

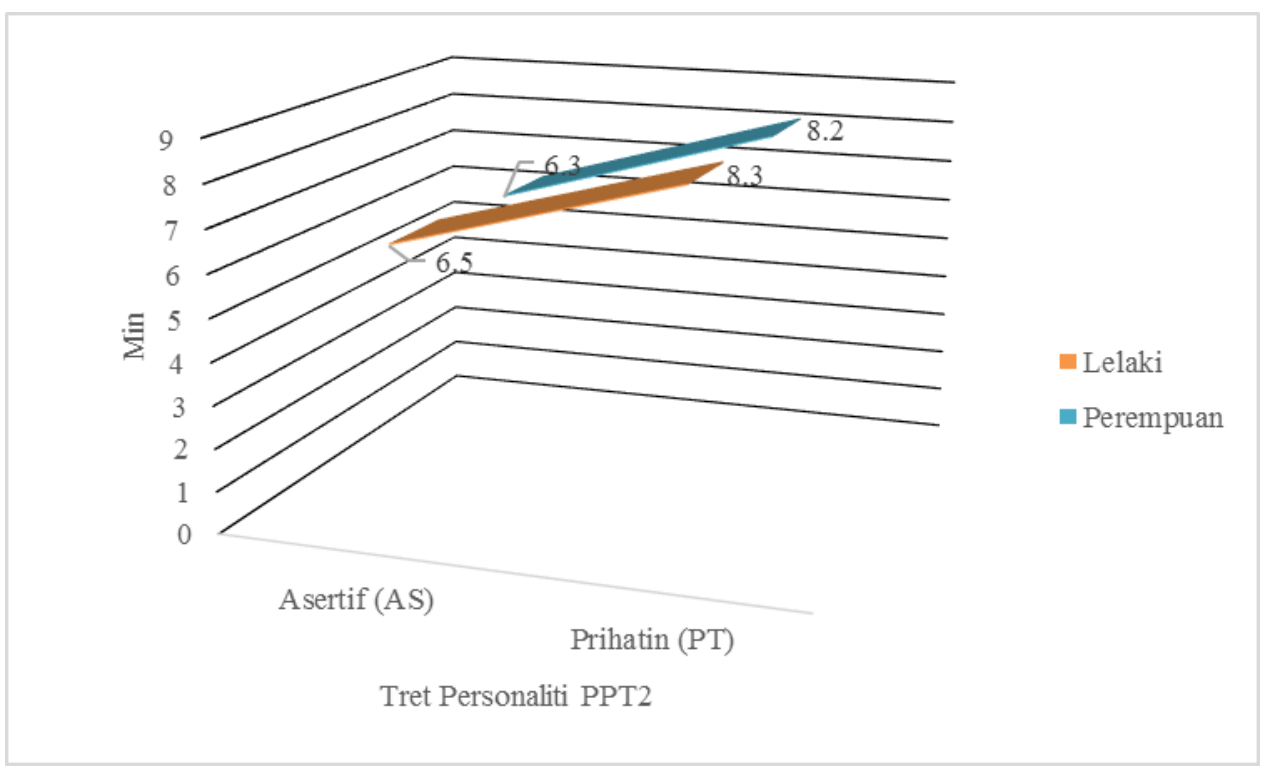

Rajah 1 Taburan min tret personaliti AS dan PT kaunselor IPT

Rajah 1 di atas menunjukkan kedudukan tret personaliti AS dan PT mengikut jantina. Tret personaliti AS secara keseluruhan adalah min 12.8 dengan kedudukan responden perempuan adalah min 6.3 berbanding dengan kedudukan responden lelaki pada min 6.5 . Kedua-dua jenis jantina responden ini berada di kedudukan sederhana iaitu di bawah min 6.5. Tret personaliti AS ini mengikut interpretasi PPT2 menggambarkan kecenderungan responden menghindari situasi konfik dengan bersikap mengalah dan adakalanya memendam perasaan tidak puas hati kepada orang lain. Walau bagaimanapun, sikap dan tingkah laku responden itu mengikut situasi dan keadaan semasa. Begitu pula, tret personaliti PT menunjukkan secara keseluruhan responden ini berada di min 16.5 dengan kedudukan responden lelaki dan 
perempuan hanya berbeza min 1.0. Tret personaliti PT responden lelaki adalah pada min 8.3 manakala kedudukan responden perempuan pada min 8.2. Persamaan tret personaliti PT kedua jantina responden ini mengikut interpretasi PPT2 adalah berada di tahap tinggi dan menggambarkan kecenderungan responden mudah mesra, keupayaan empati yang tinggi dan suka menolong tanpa mengira bangsa dan agama. Pengukuran personaliti seringkali dikritik berikutan ada kemungkinan wujud jawapan dari individu yang seolah-olah berpura-pura dalam menjalani psikometrik itu (Gregory J., 2012). Sehubungan itu, PPT2 di dalam Edisi Keduanya, menyediakan satu tret yang akan menentukan sikap kejujuran individu iaitu tret Ketidakselarasan (KS). Semakin rendah tahap tret KS PPT2 akan menggambarkan diri sebenar individu (true self) dan sebaliknya tahap tret KS semakin tinggi, akan menggambarkan individu yang cuba mempamerkan ciri-ciri diri ideal (ideal self) dirinya.

\section{Tret Ketidakselarasan (KS) Dalam PPT2}

Tret adalah suatu label tertentu yang memberikan gambaran perilaku individu mengikut sesuatu situasi (Pennington, 2003). Melalui pengukuran personaliti, tret personaliti yang tersirat kini sudah berjaya di selidik dengan ketepatan jangkaan data pengkaji dan pengamal (Gregory J.Boyle, Donald H.Saklofske, 2015). Data yang diperolehi dari kajian kuantitatif akan memberi kesan kepada proses dan perkembangan pengukuran personaliti baik secara teori mahupun operasional. Di dalam dunia psikologi, pengukuran personaliti seperti Teori Tret dan Faktor Cattell merupakan suatu kajian personaliti yang saintifik serta berupaya untuk menentukan faktor tingkah laku termasuk suatu kaedah yang berupaya menentukan tahap kejujuran klien dalam mengikuti instrumen itu (Habibah Elias dan Noran Fauziah Yaakub, 2002). Psikometrik PPT2 mempunyai keistimewaan iaitu melalui tret Ketidakselarasan (KS) akan mengukur keakuratan atau kejujuran individu.

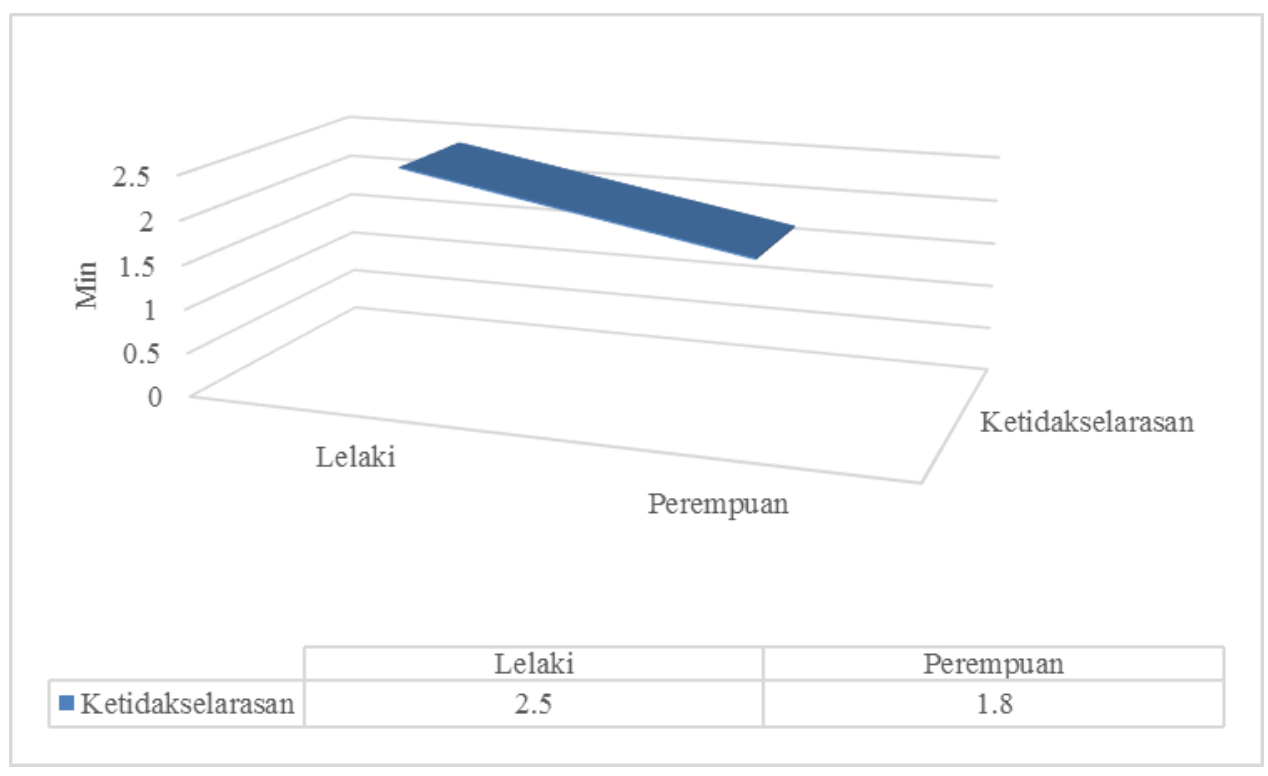

Rajah 2 Tret Ketidakselarasan (KS) kaunselor IPT

Rajah 2 di atas menunjukkan gambaran tret personaliti Ketidakselarasan PPT2 iaitu masing-masing jantina responden berada di tahap yang rendah iaitu di bawah nilai purata min 3.0. Jantina perempuan menunjukkan nilai purata terendah iaitu 1.8 dan diikuti jantina lelaki pada nilai purata min 2.5. Keseluruhannya, tret KS untuk kumpulan responden ini mempamerkan sikap jujur dan dipercayai di dalam kajian ini.

\subsection{PERBINCANGAN}

Kedudukan tahap trait personaliti AS yang rendah (nilai purata min 4.0 ke bawah akan menunjukkan semakin pasif individu, kecenderungan untuk mengalah, membiarkan diri untuk dimanipulasi oleh orang lain, dan lebih kritikal individu kecenderungan memendam perasaan berbanding menzahirkannya secara terus-terang. Begitu sebaliknya, kedudukan tahap tret AS yang tinggi (nilai purata min di atas 6.0) menunjukkan kecenderungan tingkah laku individu yang tegas dan tidak mudah mengalah. Namun, kedudukan nilai purata min tret AS yang terlalu tinggi (melebihi nilai purata min 9.5) akan menunjukkan kecenderungan individu untuk bertingkah laku agresif dan tidak akan mudah bertolak ansur. Perbincangan selanjutnya akan berfokus kepada dua (2) perspektif pertama iaitu persoalan tret AS kepada organisasi dan kedua, perspektif tret AS terhadap hubungan dengan klien melalui proses perkhidmatan kaunseling.

\section{Trait Personaliti PPT2 AS Dalam Kepentingan Kaunselor Muslim Untuk Organisasi dan Perkhidmatan Kaunseling}

Responden kajian ini menjelaskan kedudukan tahap sederhana pada kedua jantina responden berada nilai purata min 6.5. Kedudukan sederhana ini menunjukkan kecenderungan responden yang tidak mahu terlibat dalam apajua konflik di tempat kerja malahan jika konflik itu turut berlaku di persekitaran keluarga. Kecenderungan ini lebih besar terjadi sekiranya responden berkhidmat secara bersendirian di tempat kerjanya. Perjawatan responden yang dianggap sebagai pekerja teladan dan tidak mempunyai sebarang masalah oleh rakan sekerja 
menyebabkan responden perlu bersikap netral dan tidak menyebelahi mana-mana pihak. Sedangkan, sebagai kaunselor muslim yang tahu kebatasan diri di sisi Allah SWT bahawa tiada manusia yang sempurna dan manusia itu seringkali lalai serta mudah mengerjakan dosa. Kumpulan responden ini sedia mengalah atau mengikut apa jua keputusan dari pihak pengurusan tertinggi di organisasi seandainya keputusan itu memberikan manfaat yang berguna untuk diri responden baik secara jangka panjang atau jangka pendek. Pendek kata, sama ada baik atau buruk, keputusan itu, responden perlu setuju dan arahan hendaklah diikuti walaupun hakikatnya keputusan itu merugikan organisasi malahan kerjaya kaunselor itu.

Pada perspektif perkhidmatan kaunseling pula, kecenderungan responden untuk akur kepada kehendak klien walaupun sebenarnya keputusan itu sebenarnya boleh merugikan diri klien sendiri. kaunselor tidak mahu konflik klien menjebak diri kaunselor sendiri. Masalah lebih rumit sekiranya klien bermasalah di tempat kerja yang melibatkan majikan dan rakan sekerja yang lain. Hakikatnya, sebagai kaunselor muslim pendirian nilai-nilai Islam wajarlah diberi perhatian andainya masalah klien itu melibatkan penyelewengan wang atau ponteng kerja. Nilai amanah dan tanggungjawab moral dalam Islam haruslah kaunselor muslim pertahankan dan hakikat itu perlu diperjelaskan secara berhemah kepada kliennya. kaunselor muslim perlu menggunakan pendekatan kaunseling yang lain dalam usaha menilai tingkah laku klien yang salah disisi agama mahupun salah disisi nilai masyarakat. Sekiranya, trait AS ini rendah, dikhuatiri kaunselor muslim hanya menjalankan praktis kaunseling sahaja dan tidak berani untuk mencelikkan akal klien secara terang dan wajar peranan hukum-hakam Islam seperti fardu ain ataupun disisi aspek syariah.

\section{Trait Personaliti PPT2 PT Dalam Kepentingan Kaunselor Muslim UntukPerkhidmatan Kaunseling}

kaunselor yang prihatin adalah individu yang mudah membantu orang lain yang menghadapi masalah. Melalui tret personaliti PPT2, tahap tret personaliti PT yang ideal adalah sederhana tinggi (antara nilai purata min 60 hingga 90). PPT2 memberikan interpretasi individu yang mudah membantu orang lain, baik hati, dan suka menghulurkan bantuan. Dapatan kajian ini menunjukkan tret personaliti PPT2 PT berada di tahap rendah, (nilai purata min 45) . Ini amat membimbangkan kepada perjawatan kaunselor itu kerana sewajarnya trait personaliti PPT2 PT adalah tinggi di kalangan kaunselor muslim yang berkhidmat di IPT. Dapatan ini jelas memberikan isyarat awal bahawa perjawatan kaunselor secara amnya perlu ditinjau secara mendalam sama ada pengisian jawatan kaunselor itu adalah mengikut minat atau sekadar ingin bekerja di sektor perkhidmatan awam negara sahaja. Justeru itu, keperluan penyeliaan di kalangan kaunselor digalakkan (American Counseling Association Governing Council, 2015; Undang-Undang Malaysia, 1998). kaunselor merasakan tidak perlu mengisytiharkan kecekapannya kepada majikan kerana bimbang akan menjejaskan reputasinya di mata majikan. Pada perspektif perkhidmatan kaunseling, seorang kaunselor muslim wajar memerhatikan kliennya sama ada kebajikan atau aspek-aspek persekitaran klien ada yang mempengaruhi tingkah lakunya. Seorang kaunselor muslim yang benar prihatin, sudah mempunyai rekod atau catatan sampingan sebelum proses kaunseling berlangsung. Firman Allah,

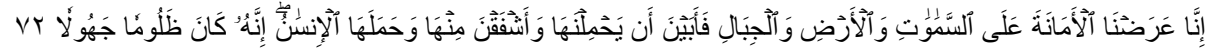

Surah al-Ahzab, ayat 72

"Sesungguhnya kami menurunkan amanat iaitu tugas-tugas kepada langit, bumi dan gunung-gunung. Semuanya enggan memikul amant itu kerana mereka khuatir kelak mereka mengkhianatinya. Akhirnya, manusialah yang memikul amanat itu. Sesungguhnya, manusia itu zalim dan bodoh".

\section{Rumusan}

Tidak dinafikan dapatan tret personaliti PPT2 membantu pihak pengurusan ataupun bersesuaian dengan pelan perancangan penyeliaan untuk kaunselor. Seterusnya, data yang disediakan oleh PPT2 mampu untuk menjadi data pintar untuk menyokong rancangan diagnosis kompetensi kaunselor dalam mencapai hala tuju yang dinamik mengikut trend masyarakat dan situasi yang berlaku masa kini. Dapatan tret personaliti PPT2 memberikan suatu panduan dalam menyusun semula kemahiran dan kompetensi sedia ada pada kaunselor muslim di IPT. Kajian tinjauan ini mempunyai kekurangannya iaitu tidak memperincikan faktor demografi yang lain seperti tahun pengalaman berkhidmat dan umur dalam perolehan tret personaliti PPT2. Di samping itu, jumlah responden yang dikaji tidak memberikan gambaran sebenar kepada tret personaliti PPT2 kaunselor muslim yang berkhidmat di semua IPT. Walau bagaimanapun, kajian ini memberikan gambaran awal keberkesanan personaliti kaunselor muslim masa kini khususnya di sektor awam di Malaysia.

\section{Rujukan}

Ab Rahim Bakar, Noor Syamilah Zakaria, \& Shamsiah Mohamed. (2011). Malaysian Counselors' Self-Efficacy: Implication for Career Counseling. International Journal of Business and Management, 6(9), 141-147. http://doi.org/10.5539/ijbm.v6n9p141

Ab. Halim Tamuri, Muhamad Faiz Ismail, K. A. J. (2012). Komponen Asas Untuk Latihan Guru Pendidikan Islam. Global Journal Al-Thaqafah, 2, 53-63. http://doi.org/10.7187/GJAT232012.02.02

Abdul Hafiz Mat Tuah, Zakaria Stapa, \& Ahmad Munawar Ismail. (2012). Memperkasakan Jati Diri Melayu Muslim Menerusi Pendidikan Islam Dalam Pengajaran Akhlak. Jurnal Hadhari Special Edition, 23-35.

Abdul Mun'im Al Hasyimi. (2012). Indahnya Akhlak Rasul SAW: Menurut Bukhari dan Muslim. Inteam Publishing, Kuala Lumpur.

Akbariah Mohd Mahdzir. (2015). Introductory Rasch Model Workshop: Application in Survey Research and Educational Measurement. Bangi, Selangor.

American Counseling Association Governing Council. (2015). ACA release FAQs for licensure policies. Counseling Today, 54-55.

Bembenutty, H. (2010). The Last Word : Interview with Wilbert J McKeachie-The Teacher of Teacher Teachings' Tips and Strategies. Journal of Advanced Academics, 21(3), 530-544. http://doi.org/10.1177/1932202X1002100307

Buerah Tunggak, H. (2011). Keperluan latihan dan pendidikan berterusan ke arah pembangunan usahawan Muslim berteraskan nilai Islam di Malaysia. Jurnal Teknologi, 55, 121-144.

Chickering, A. W. (2010). A Retrospect on Higher Education's Commitment to Moral and Civic Education. Journal of College \& Character, 11(3), 1-7. http://doi.org/10.2202/1940-1639.1723 
Chua Yan Piaw. (2012). Mastering Research Methods. McGraw-Hill, Shah Alam, Selangor.

Dewan Bahasa Pustaka. (1991). Kamus Dwibahasa Bahasa Inggeris-Bahasa Malaysia. Dewan Bahasa dan Pustaka, Kuala Lumpur.

Dinkelman, T. (2011). Forming a teacher educator identity: uncertain standards, practice and relationships. Journal of Education for Teaching, 37, 309-323. http://doi.org/10.1080/02607476.2011.588020

Geramian, S. M., Mashayekhi, S., \& Mohd Tajudin Ninggal. (2012). The Relationship Between Personality Traits of International Students and Academic Achievement. Procedia - Social and Behavioral Sciences, 46(1996), 4374-4379. http://doi.org/10.1016/j.sbspro.2012.06.257

Gregory J., G. M. and D. H. S. B. (2012). Contribution of Cattellian Personality Instruments. In D. H. S. \& G. M. George J. Boyle (Ed.), SAGE Benchmarks In Psychology: Psychological Assessment Volume 2 Personality and Clinical Assessment, 489. SAGE Publications Ltd., London.

Gregory J.Boyle, Donald H.Saklofske, G. M. (2015). Criteria for Selection and Evaluation of Scales and Measures. In G. M. Gregory J.Boyle, Donald H.Saklofske (Ed.), Measures of Personality and Social Psychological Constructs. 1, 18-30. Elsevier Inc., London.

Gregory J.Boyle, G. M. and D. H. S. (2008). Personality Measurement and Testing: An Overview. In The SAGE Handbook of Personality Theory and Assessment: Personality Measurement and Testing. 1-26. Sage Publicatios, London.

Habibah Elias dan Noran Fauziah Yaakub. (2002). Psikologi Personaliti. 2nd edition. Dewan Bahasa dan Pustaka, Selangor, Malaysia.

Harris, D. N., Ingle, W. K., \& Rutledge, S. a. (2014). How Teacher Evaluation Methods Matter for Accountability: A Comparative Analysis of Teacher Effectiveness Ratings by Principals and Teacher Value-Added Measures. American Educational Research Journal, 51(1), 73-112. http://doi.org/10.3102/0002831213517130

Hasan Langgulung. (1997). Pengenalan Tamadun Islam Dalam Pendidikan. Dewan Bahasa dan Pustaka, Kuala Lumpur.

Haslina Hanapi. (2012). Teori Ujian Klasikal (TUK) dan Teori Respon Item (RTI). Al-Mizan Jurnal Akademik, Institut Pendidikan Guru Kampus Sultan Mizan, Besut, Terengganu, 5(1), 107-115.

Hishamuddin Abdul Hamid, Mohd Isa Hamzah, Rohizan Ya, Suriani Abd Rahim, \& Khairul Najah Abdul Rahim. (2012). Konsep Pendidikan Islam Melalui Pendidikan Akidah Islamiah: Kesannya Terhadap Pembentukan Akhlak Pelajar Muslim Masa Kini. In Prosiding Wacana Pendidikan Islam Siri Ke-9 Peringkat Serantau, 275-284.

Ismail, A. M., \& Yusuf, N. (2012). Sumbangan Pendidikan dalam Memperkasakan Tamadun Bangsa : Perspektif Islam. Sosiohumanika, 5, 107-122.

Kementerian Pendidikan Malaysia. (2012). Laporan Awal-Ringkasan Eksekutif Pelan Pembangunan Pendidikan Malaysia 2013-2025. Vasa. Retrieved from http://moe.gov.my/userfiles/file/PPP/Preliminary-Blueprint-ExecSummary-BM.pdf

Kementerian Pendidikan Malaysia. (2015). Bahagian Psikologi dan Kaunseling. Retrieved from http://www.moe.gov.my/my/profil-jabatan?div=13

Komarraju, M., Karau, S. J., Schmeck, R. R., \& Avdic, A. (2011). The Big Five personality traits, learning styles, and academic achievement. Personality and Individual Differences, 51, 472-477. http://doi.org/10.1016/j.paid.2011.04.019

Martyn Long. (2000). The Psychology of Education. London and New York. Retrieved from www.psych-ed.org.

Millon, J. M. \& T. L. (2003). Handbook of Psychology. (I. B. Weiner, Ed.). 5th edition. John Wiley and Sons,Inc., New Jersey.

Mizan Adiliah Ahmad Ibrahim. (2001). Pengurusan Perkhidmatan Personalia Murid. Cerdik Publications Sdn Bhd., Shah Alam, Selangor.

Mohamed Hatta Shahrom. (2008). Sifat Pengamal Perubatan. In Mohamed Hatta Shahrom, Anisah Che Ngah, Susan Tan Mooi Koon, Abdul Hamid Abdul Rahman, \& Hatta Sidi (Eds.), Etika Perubatan Islam Dan Isu-isu Psikiatri. First Edition. 9-18. Dewan Bahasa dan Pustaka, Kuala Lumpur.

Mohd Fauzi Hamat. (2005). Ketokohan Al-Ghazali dalam Bidang Logik. Penerbit Universiti Malaya, Kuala Lumpur.

Mohd Puzhi Usop. (2013). Ar Rahmah: Terjemahan Al-Hidayah Al-Quran Al-Karim (Rasm Uthmani Dalam Bahasa Melayu). in R. R. Maheran Ahmad, Mohd Khairul Nizam Zainan Nazri, Muhammad Sabri Sahrir, Nor Hasanuddin H.M. Fauzi, Hakim Zainal, Nor Syahida Ahmad, Mohd Bakri Aziz, Noraine Abu, (Eds) Al Hidayah House of Qur'an Sdn Bhd., Batu Caves. Retrieved from www.hidayah.com.my

Mohd Tajudin Ninggal. (2012). TAJMA Personality Profile 2nd Edition (TPP2). Malaysia. Retrieved from www.tajma-psychometric.com.my

Mohd Tajudin Ninggal. (2014). TAJMA: Personality Profilling \& Certification Workshop. Malaysia. Retrieved from http://tajma-consulting.utm.my

Muhadir Hj Joll. (2014). Kenal Untuk Cinta dari tarikh al hawa dits wa alahwal an nabawiyyah oleh Sayyid Muhammad bin Alawi Al Maliki. (Dari buku tarikh al hawa dits wa alahwal an nabawiyyah oleh Sayyid Muhammad bin Alawi Al Maliki, Ed.). Galeri Ilmu Sdn Bhd., Selangor, Malaysia.

Muhammad Al-Ghazali. (2002). Akhlak Seorang Muslim. Crescent News (KL) Sdn Bhd., Kuwait.

Muhammad Uthman Najati. (2012). Pandangan Al-Quran Terhadap Jiwa Manusia (Al-Quran Wa 'Ilm al-Nafs). Penterjemah HadiyanJauzi (eds.). Perniagaan Jahabersa, Johor Bahru, Malaysia,

Muhd Mansur Abdullah. (1993). Kaunseling: Teori,Proses dan Kaedah. Edisi Kedua. Penerbit Fajar Bakti Sdn Bhd., Johor Bahru, Malaysia.

Neufeldt, V. (Ed.). (1994). Webster's New World Dictionary Of American English. Third Edition. Prentice Hall, New York.

Openshaw, K., Linden, K. W., \& Linden, J. D. (1969). A Longitudinal Study of Teachers' Attitudes and Personality Characteristics. Journal of Teacher Education, 20(3), 351-360. http://doi.org/10.1177/002248716902000315

Pahrol Mohamad Juoi. (2010). Mukmin profesional celik mata hati: 7 langkah memperkasa diri. Telaga Biru Sdn Bhd, Kuala Lumpur.

Pennington, D. C. (2003). Essential Personality. Hodder Education, London.

Rasm Uthmani. (2014). Al Qur'an Pelangi Terjemahan dan Tajwid Berwarna. PDI Publications Sdn. Bhd., Kuala Lumpur.

Ratna Roshida Abd. Razak, \& Nik Haslinda Nik Hussain. (2007). Peranan Institusi Keluarga Dalam Penjanaan Bangsa Bertamadun. Jurnal Kemanusiaan, 9, 73-82. Retrieved from http://myais.fsktm.um.edu.my/8354/

Rusleda Awang, Wan Kamal Mujani, K. A. G. (2012). Potensi Manusia Menurut Pemikiran Hassan Langgulung. Jurnal IPG Kampus Islam, 1-20.

Sayyid Mujtaba Musavi Lari. (1995). Psikologi Islam: Membangun Kembali Moral Generasi Muda. in Ali Husain. Edisi kedua. Pustaka Hidayah, Bandung. Sidek Mohd Noah. (2006). Perkembangan Kerjaya: Teori dan Praktis. Penerbit Universiti Putra Malaysia, Serdang, Selangor.

Suhid, A. (2012). Gagasan Pemikiran Falsafah dalam Pendidikan Islam : Hala Tuju dan Cabaran. Journal of Islamic and Arabic Education, 4, 57-70.

Undang-Undang Malaysia. Akta kaunselor 1998, Pub. L. No. AKTA KAUNSELOR 1998 (1998). Percetakan Nasional Malaysia Berhad, Malaysia.

Urusetia Lembaga kaunselor Kementerian Pembangunan Wanita Keluarga dan Masyarakat. (2015). Direktori kaunselor. January 1, 2015, http://www.kpwkm.gov.my/lkm/

Yatimah Sarmani dan Mohd Tajudin Ninggal. (2008). Teori Kaunseling Al-Ghazali. PTS Publications \& Distributors Sdn. Bhd., Batu Caves.

Zakaria Stapa, Noranizah Yusuf, A. F. S. (2012). Pendidikan Menurut Al-Quran dan Sunnah serta Peranannya dalam Memperkasakan Tamadun Ummah. Jurnal Hadhari Special Edition, 7-22. 